\title{
Effects of a Quality Management System on the Financial Performance in Banking Sector: Case Study Kosovo
}

\author{
PhD Cand. Samir Lleshi \\ Lirim Lani
}

\begin{abstract}
Creating and improving the services quality, presses the financial institutions to make differentiation from the competition and better position in market for itself. The modern approach to quality management system in the financial and banking sector includes faith, activities which make the client satisfied and this is particularly true in the goodness and help the employees with whom customers will come in contact giving accurate and clear information, discipline and long-term approach. The objective of this study was to establish the effect of quality management system on financial performance in the Kosovo banking sector. At the same time, the concept of quality as a rule leads to confusion and misinterpretation, because it is difficult to determine its exact meaning. The quality of the product or service is the first and often the last thought of the people, when they talk about quality. The concept of quality as an indicator of fulfilling the requirements of the standards or level of excellence is part of advertising, when it comes to their product or service. In tackling the problem, we used empirical methods, which will enable us a correct result of our paper. The results of the paper does not result in significance between banking services and performance of the banking sector in Kosovo.
\end{abstract}

Keywords: Quality management, financial services, customer, banking sector, quality dimensions

JEL Classification:M-10; L-15; G-21 / UDC Classification: 005. 6. 336. 7

\section{Introduction}

In the conditions of globalization, growing competition and lack of differences in banking markets, quality of service becomes a decisive factor of survival and success of banks. Customers come to the center of the business philosophy, and they are those that require new products, better, faster and more reliable service. In such environment, banks must meet or exceed the expectations of increasingly demanding customers. High-quality service is a way to achieved customer loyalty, facilitate the cross-selling of banking products, that ensuring greater market share and, at the same time, reducing operational costs, which will ultimately lead to increased profitability.

The banking sector in Kosovo has been dedicated to improving the quality of the customer service for years, and it has intensified its investment in banking technology. Commercial banks through the adoption of new technologies have enabled access to businesses and customers in the global financial markets, and have aligned the economy of Kosovo with the global economy. Only with continuous adjustment, fast decision making and adequate changes, organizations can survive in turbulent markets and increasingly complex doing business in order to achieve the expected success. Therefore, the quality of products and services is imposed as a strategic objective that organizations seek to achieve, thus, it is imposed as a competitive factor which has a significant impact on the performance of doing business. Quality management is a revolutionary step in increasing business efficiency, which is equally important for all banks, regardless of their size. This activity is focused on general improving of the Bank operations, which reduces costs, raises the employee morale and constantly improves the quality of products and services. This affects the competitive position of banks in the market toward the strengthening of the faith of the users themselves. The bank also constantly strives to win new elements of the quality, aiming to achieve the competitive advantage.

The goal of any organization is to achieve and maintain the competitive advantage. One way to achieve this objective is that the organization is faster and better in fulfilling the desires of the users compared with the competition. Acting in this way they are trying not only to meet, but also exceed the expectations of the users, and create the opinion among them 
that competition is not in good condition and adequate to meet their needs. To achieve this it is not an easy and simple task, where quality management systems are responsible for achieving the goals of the quality to of the determined objectives. Aiming to gain the importance of the quality, which belongs to it, specific circumstances should be created which should be included along with modern technological development, including the severe competitive race, particularly expressed in the global market. Thus, in such circumstances, the quality can play a role as a strategic weapon in an attempt to keep the existing and the new markets. Every organization applies a special system of quality management, including banks as institutions with significant amounts of capital employed, number of employees and a complex organizational structure, generally recognized with the quality importance upon the offering of the services, mainly they have recognized the importance of quality in the case offering of the services, and therefore most of the banks implemented a formal system of quality management.

The economic crisis in Europe, and on the other hand the partnership between states and the lack of economic, political and social stability, has affected the investment and development of the economy in general. The economy of Kosovo has continued its growth trend despite the unfavorable international situation. In this way, it has managed to maintain macroeconomic balance It is important to know whether the banks do understand the current consumer needs and if the efforts they make meet the said needs. Thus, the management of service quality and consumer satisfaction is an essential task for finance- banking institutions in Kosovo.

\section{Literature Overview - Importance of QMS and quality on banking rervices}

The standard ISO 9001 defines the process as an activity or group of activities that uses resources to return input values into the output values. (ISO 9001:2015). Each organization contains a certain number of more or less interrelated processes, which are ultimately important for the quality of the product. Quality of service at the present time has become a prerequisite for economic efficiency and a major driving force of the activities of successful organizations. Although there are a large number of definitions for the quality, the most widely accepted is the one that puts customers at the center and the fulfillment of its requirements. The Quality of management in the banking system includes security system, and focuses on what the user wants to speed up and facilitate the use of banking services. A major role in establishing relationships with customers belongs to the employees, that is, the involvement of employees in banking activities is necessary to enhance the quality of products and services. The prerequisite for this is an understanding of the employees in each segment and those who are in constant touch with some customers. In the quality and competitiveness, the development and application of new technologies has also a significant impact. Quality of services is the most important aspect in banking, as well. Business success can be reinforced if you conscientiously search for newer and more effective ways of improving the quality of your ways of serving customers. Quality is vital for organization success. It has become inevitable for banks to work on enhancing quality within their functions, product and services and the way they manage their organizations. Quality denotes an excellence in goods and services, especially to the degree they conform to requirements and satisfy customers (Islam. A. and Haque, A. F. M. 2012).

When it comes to quantitative benefits, a study was conducted back in mid 1990s, particularly covering American banks, from the point of view of service quality improvement. The study showed that improvement of service quality may increase the returns in a bank (Harvey, 1996, p. 11). As shown in Table 1 below, according to the data from this study, the improvement of service quality resulted in increased returns on assets (ROA) from 1. $05 \%$ to $1.38 \%$, and increased return on capital (ROE) from $16.10 \%$ to $21.22 \%$.

\begin{tabular}{|l|l|l|}
\hline $\begin{array}{l}\text { Type of Bank } \\
\text { Performance }\end{array}$ & Before Service Improvement & After Service Improvement \\
\hline ROA & $1.05 \%$ & $1.38 \%$ \\
\hline ROE & $16.10 \%$ & $21.22 \%$ \\
\hline
\end{tabular}

Source: Harvey, T. (1996), p. 11

Adopting QMS at the level of the organization is a strategic decision that "directs and controls the organization in terms of quality", aiming to improve its efficiency and effectiveness in order to increase the satisfaction of stakeholders by meeting their requirements. A qualitative QMS does not in itself make an organisation more profitable, efficient or customer focussed, but it will give to an organisation the ability to do anything better, from production to sales. A Quality Management System can be seen as a complex system consisting of all the parts and components of an organisation dealing with the quality of processes and products. A QMS can be defined as the managing structure, responsibilities, procedures, 
processes, and management resources to implement the principles and action lines needed to achieve the quality objectives of an organisation. The importance and increasing attention to service quality in financial institutions is fully justified by the sociopolitical changes that have arisen (Cowling \& Newman, 1995). As quality is defined as the totality of characteristics of a product that bears on its ability to satisfy stated and implied needs, customer's satisfaction measurement appears as the most objective way of global assessment of the quality level of a given product. Customer's satisfaction is an essential measure that should have a status in corporate culture and effect until process improvements. Quality management as well as business strategies recognize the vital importance of customer's satisfaction to the success of an organisation (Ahonen, 1999). The quality service does not happen itself, but comes as the result of the quality of work of all those involved in its creation. Thus, the quality of the management processes beyond the scope of producing or offering of the services, while covering all functions of the organization and all individuals within the organization, as well as those which may affect the quality of its products or services. The basic elements of the quality are determined to help companies that are focused on the quality to constantly improve their results, while following the consumers, as well as other stakeholders. The satisfaction of the consumer is defined as follows: "The satisfaction of the consumer is the consumer's reaction to a self-fulfilling experience or a part of it" (Buttle, 2011). Upon the building of the quality relationships with customers, the bank can satisfy more customers than its competitors and better understand their needs. Most banks in Kosovo have intensified their investment in banking technology in order to divert customers from bank counters in order to reduce the costs. On the other hand the literature suggested that for banking customers personal relationships are still preferred as a primary means of communication and exchange between the bank and clients. (Tyler and Stanley, 2001).

Main banks of Kosovo are owned by foreign banks, which operate under the Basel standards, and have a much elaborated system of management user system. Based on research conducted for customer satisfaction in the bank, it is estimated that bank competitions mostly affect their ability to offer banking services, the development of technology that ensures fast and easy use of banking products by the user and the way banks interact with customers. Major objections in operation of bank the surveyed have on terms of loans, due to the lack of transparency, complex procedures, as well as rates of higher interests. The surveyed also see the quality of bank as a communication of banks with customers. In recent years, banks, due to increased competition, have developed more diversified services with the highest quality in order to survive and operate profitably. (T. Sadeghi, Bemani A. 2015).

Almost all Kosovar commercial banks have focused, till recently, on certain categories of clients when presenting. The main goal is to improve customer service and increase his delight. As a continuing relationship is the relationship with the client must provide that security, sense of control and a sense of trust, minimize risks, and ultimately lower costs. (Gronroos, 2004). One factor that may have an impact on customer loyalty to banks, are interpersonal relationships. Personal relationships can help to build long-term bilateral relations that make the customer perceives as the service gets differentiated services that offer other banks (Berry, 1995). Do the banks clients feel so in Kosovo? The undertaken researches from the researchers have found that banks that are oriented from the clients keep their customers longer, indicating that they are satisfied (Appiah et al, 2001). In order to create a quality management model for banking services, it had been necessary to determine the specifics of banking services, to analyze various theories of the customer satisfaction genesis, make a comparison of different models for measuring customer satisfaction and analyze the advantages and disadvantages of quality management models in banking. Why does customer satisfaction matter? There are two reasons. Customer satisfaction shows whether we are doing the right things and whether we are doing them in the right way. A customer is the only financial contributor and in times of harsh competition customer satisfaction plays a more and more important role in making a purchase decision (Goodman and Colin 1992). Finally, should always bear in mind that the customers always give priority to those service providers who offer the highest quality at the most acceptable price. Quality should be valued by the customers and should always be put in relation to their needs and expectations (Nagaprasad, H. and Yogesha, B 2009).

\section{Methodology and Data}

The paper uses secondary data to measure financial performance indicators of the financial sector, with a special emphasis on the banking sector in Kosovo for the period 2000-2015, the data source of the paper are based on the annual reports of the Central Bank of Kosovo for the financial performance indicators of the banking sector, as well as data on the quality of the services of the banking sector in Kosovo. Some financial indicators during the reporting periods are missing, as in the period after the war in Kosovo (1999), the data were not presented in the absence of credible data and for other reasons. The sample of the paper consists of 10 commercial banks in Kosovo, which are owned by different, with most dominant 
foreign capital, while a small part of the local capital, and sample of the paper includes the structure of some electronic services and physical commercial banks in Kosovo, which shall be treated through social science program SPSS statistical, empirical methods for testing the hypothesis of the paper. If the P-value $\leq a$, then we reject the null hypothesis, whereas starting if $\mathrm{P}$-value $>\mathrm{a}$, then do not reject the null hypothesis.

\section{Hypotheses}

The main hypothesis of this paper is:

$\mathrm{H}_{0}$ - Application of Quality Management System (QMS) in the banking sector services does not have impact in the performance of banking sector in Kosovo;

$\mathrm{H}_{1}$ - Application of Quality Management System (QMS) in the banking sector services have impact in the performance of banking sector in Kosovo;

Variables

In determining the performance of the banking sector have used financial indicator of profitability, as key elements for description of the performance of the banking sector. Professor Ameen (et al, 2015), in determining of the performance of the banking sector has used these financial indicators in their empirical analysis, through financial indicators of profitability. QMS in our work will be treated in terms to offer banking services to customers of banks in Kosovo. In determining the elements of the quality services offered by banks in Kosovo are limited, because the banking sector of Kosovo is still in its development stages, so we have restrictions on use of the elements of the definition of services of commercial banks in Kosovo.

\section{Profitability of banks is measured by:}

Return on Assets $(\mathrm{ROA})=$ net profit $/$ total assets is a measure of profitability that shows how the bank performs services related to its full potential. Return on assets ratio measures the net income in relation to total assets. This report indicates the return on all assets of the bank after they pay interest and taxes. This report shows how well a bank is managed as it shows how profit is created for each unit of average assets. Return on assets ratio is a ratio which is used quite a lot in the empirical analysis of capital adequacy as it permits comparison between banks of different sizes;

Table 1. ROA in the banking sector in Kosovo (2000-2015)

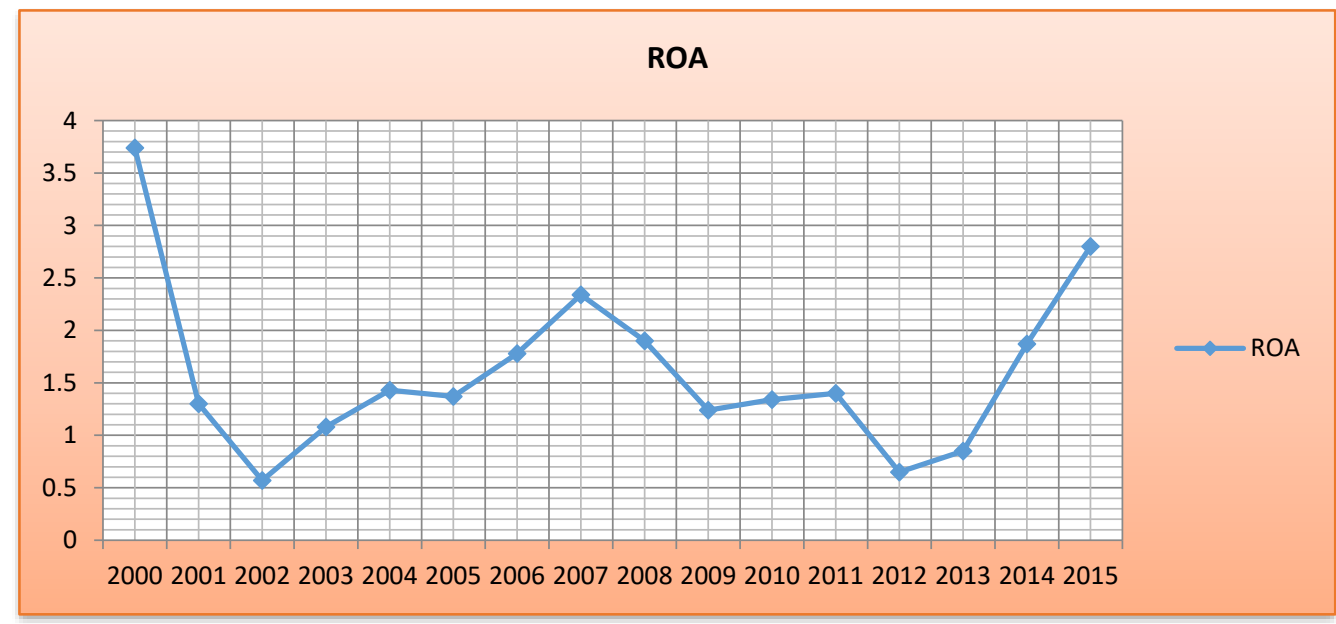

Source: CBK Annual reports and statistical reports, 2000-2015 
Return on Equity $(\mathrm{ROE})=$ net profit $/$ total equity represents shareholders report which invest to ensure a return on their money and this report shows how well I was progressing investment accounting terms. ROE is inverse indicator between profitability and risk that the bank undertakes, and a good indicator for comparing performance between banks

Table 2. ROE in the banking sector in Kosovo (2000-2015)

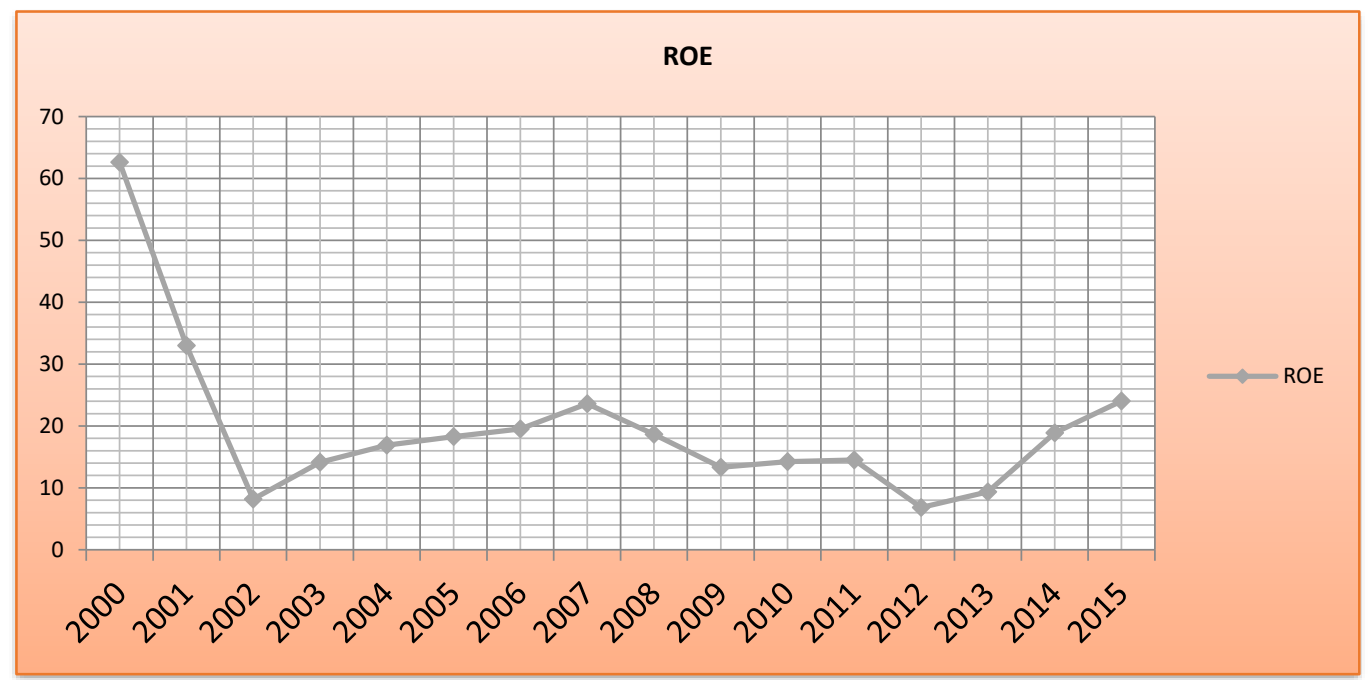

Net Margin Ratio $=$ net profit $/$ sales profit after tax shows that the bank is able to generate from its banking operations.

Source: CBK Annual reports and statistical reports, 2000-2015

Table.3 NMR in the banking sector in Kosovo

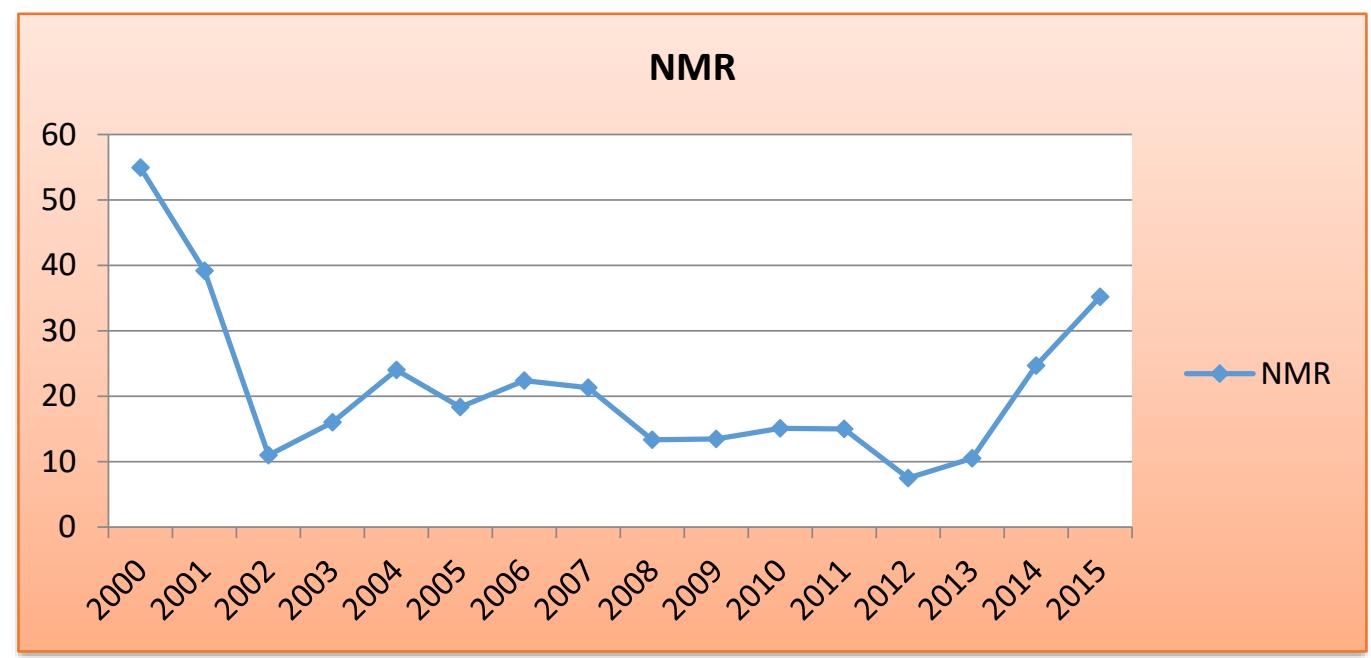

Source: CBK Annual reports and statistical reports, 2000-2015 
In terms of the data services of the banking sector in Kosovo (2001-2015), the variables were limited, since empirical Analyze quantitative data are missing, as such, only a few elements of banking services to their customers have been used. Services that affect the achievement of customer satisfaction, which have direct and indirect impact on the performance of the banking sector are closely related to their quality, because poor quality services affect poor performance of banks, and vice versa.

Table 4. Services banking sector in Kosovo (2000-2015)

\begin{tabular}{|l|l|l|l|l|l|}
\hline Years & NB & NE & ATM & POS & E_Banking \\
\hline 2001 & 28 & 637 & - & - & - \\
\hline 2002 & 118 & 1393 & 14 & - & - \\
\hline 2003 & 147 & 1676 & 35 & - & - \\
\hline 2004 & 207 & 2068 & 43 & - & - \\
\hline 2005 & 224 & 2341 & 102 & 1406 & 837 \\
\hline 2006 & 220 & 2416 & 116 & 1767 & 3316 \\
\hline 2007 & 235 & 2715 & 155 & 2554 & 4742 \\
\hline 2008 & 287 & 3607 & 240 & 3426 & 13051 \\
\hline 2009 & 292 & 3444 & 339 & 5251 & 40924 \\
\hline 2010 & 303 & 3768 & 415 & 6194 & 55292 \\
\hline 2011 & 310 & 3728 & 460 & 7534 & 68992 \\
\hline 2012 & 310 & 3727 & 483 & 8592 & 68990 \\
\hline 2013 & 305 & 3549 & 496 & 9071 & 131365 \\
\hline 2014 & 268 & 3510 & 498 & 9349 & 157761 \\
\hline 2015 & 255 & 3510 & 540 & 9705 & 187297 \\
\hline
\end{tabular}

Source: CBK Annual reports and statistical reports, 2000-2015

Table. 4 reflects NB- number of branches and sub-branches of commercial banks in Kosovo, MAILING number of employees in the banking sector, the number of ATM-s, POS and E-Banking- number of users this service over the years in Kosovo. The data are presented from 2001-2015, where some data are missing, due to the annual reports of disappearances in CBK's.

Statistical analysis and hypothesis testing

In statistical analysis the descriptive analysis shall be included, correlation and simple linear regression in testing of the paper hypotheses. Statistical analysis will show us the main elements of the performance indicators of the banking sector and the banking sector quality services at a better reflection of the empirical results of the paper. Descriptive analysis will include all the economic variables of the paper, in order to facilitate our empirical analysis.

Table 5. Descriptive analysis of all economic variables

Statistics

\begin{tabular}{|c|c|c|c|c|c|c|c|c|c|}
\hline & & NB & NE & ATM & POS & E_Banking & ROE & ROA & NMR \\
\hline & Valid & 15 & 15 & 14 & 11 & 11 & 16 & 16 & 16 \\
\hline & Missing & 1 & 1 & 2 & 5 & 5 & 0 & 0 & 0 \\
\hline Mean & & 233. 93 & 2805.93 & 281.14 & 5895.36 & 66597.00 & 19. 754375 & 1. 603750 & 21. 360625 \\
\hline Median & & 255.00 & 3444.00 & 289.50 & 6194.00 & 55292.00 & 17. 595000 & 1. 385000 & 17.165000 \\
\hline
\end{tabular}




\begin{tabular}{|l|l|l|l|l|l|l|l|l|} 
Mode & 310 & 3510 & $14 a$ & $1406 \mathrm{a}$ & $837 \mathrm{a}$ & $6.8300 \mathrm{a}$ & $.5700 \mathrm{a}$ & $7.4900 \mathrm{a}$ \\
Std. Deviation & 81.771 & 1004.098 & 199.968 & 3185.078 & 65494.049 & 13.1609959 & .8151718 & 12.4271785 \\
Variance & 6686.495 & 1008212.495 & 39987.055 & 10144720.455 & 4289470485. & 173.212 & .665 & 154.435 \\
Skewness & -1.358 & -.870 & -065 & -.230 & .001 & 2.526 & 1.300 & 1.564 \\
$\begin{array}{l}\text { Std. Error of } \\
\text { Skewness }\end{array}$ & 580 & .580 & .597 & .661 & .661 & .564 & .564 & .564 \\
Kurtosis & 1.571 & -.333 & -1.862 & -1.720 & -.610 & 7.813 & 2.064 & 2.481 \\
Std. Error of Kurtosis & 1.121 & 1.121 & 1.154 & 1.279 & 1.279 & 1.091 & 1.091 & 1.091 \\
Minimum & 28 & 637 & 14 & 1406 & 837 & 6.8300 & .5700 & 7.4900 \\
Maximum & 310 & 3768 & 540 & 9705 & 187297 & 62.6200 & 3.7400 & 54.9300 \\
Sum & 3509 & 42089 & 3936 & 64849 & 732567 & 316.0700 & 25.6600 & 341.7700 \\
\hline
\end{tabular}

\section{Source: author / Calculation SPSS 1}

Descriptive analysis results indicate that the banking sector in Kosovo have fluctuated in different periods of time, where: Monthly ROA in the banking sector in Kosovo is $1.60 \%$, with the percentage motility of $12: 57 \%$ to $3.74 \%$, while ROE has average $19.75 \%$ with mobility rate from $6.83 \%$ to $62.62 \%$ and $21: 36 \%$ NMR. Profitability indicators show that the banking sector is performing better than at the beginning of its operation, with banking services which in relation to the structure of deposits and loans is worse, because it has a low average of ATMs and users of electronic banking services, while the structure of branches and subsidiaries is better, with an average of 233 banking units and the average number of employees in 2805 .

Table 6. Correlation of all economic variables

\begin{tabular}{|c|c|c|c|c|c|c|c|c|c|}
\hline \multicolumn{10}{|c|}{ Correlations $\mathrm{a}^{\mathrm{a}}$} \\
\hline & & NB & NE & ATM & POS & E_Banking & ROE & ROA & NMR \\
\hline \multirow{2}{*}{ NB } & Pearson Correlation & 1 & 914 & 713 & 632 & 305 & -.751 & -.576 & -.627 \\
\hline & Sig. (2-tailed) & & 000 & 014 & 037 & 363 & 008 & 064 & 039 \\
\hline \multirow{2}{*}{ NE } & Pearson Correlation & .914 & 1 & 850 & 780 & 546 & -.483 & .244 & -.293 \\
\hline & Sig. (2-tailed) & 000 & & 001 & 005 & 082 & 133 & 470 & 381 \\
\hline \multirow{2}{*}{ ATM } & Pearson Correlation & 713 & 850 & 1 & 988 & 868 & -.402 & -157 & .004 \\
\hline & Sig. (2-tailed) & 014 & 001 & & 000 & 001 & 220 & 644 & 990 \\
\hline \multirow{2}{*}{ POS } & Pearson Correlation & 632 & 780 & 988 & 1 & 910 & -.366 & .127 & 059 \\
\hline & Sig. (2-tailed) & 037 & 005 & 000 & & 000 & 268 & 710 & 864 \\
\hline \multirow{2}{*}{ E_Banking } & Pearson Correlation & 305 & 546 & 868 & 910 & 1 & -.033 & 176 & 407 \\
\hline & Sig. (2-tailed) & 363 & 082 & 001 & 000 & & 923 & 605 & 214 \\
\hline \multirow{2}{*}{ ROE } & Pearson Correlation & -.751 & -.483 & -.402 & -.366 & .033 & 1 & 953 & 848 \\
\hline & Sig. (2-tailed) & 008 & 133 & 220 & 268 & 923 & & 000 & 001 \\
\hline \multirow{2}{*}{ ROA } & Pearson Correlation & -.576 & -.244 & -.157 & -.127 & 176 & 953 & 1 & 883 \\
\hline & Sig. (2-tailed) & 064 & 470 & 644 & 710 & 605 & 000 & & 000 \\
\hline \multirow{2}{*}{ NMR } & Pearson Correlation & -.627 & -.293 & 004 & 059 & 407 & 848 & 883 & 1 \\
\hline & Sig. (2-tailed) & .039 & \begin{tabular}{|l|}
.381 \\
\end{tabular} & 990 & 864 & 214 & .001 & 000 & \\
\hline
\end{tabular}


Source author / Calculation SPSS 2

Relevance correlation between economic variables descriptive and significances draws connections between them. The above link correlation between variables is between ATM and NMR's, but the economic analysis it is not a theoretical basis for the correlation analysis. Strong positive link between ROA, ROE and NMR shows that the banking sector has a good performance, so magnified as an indicator of profitability will grow another financial indicator.

To test the hypothesis of the paper we used simple linear regression, where the model is constructed on the basis of existing data which are based on the analysis above. Dependent variable are taking the performance of the banking sector, ie we used the average of the combination of three indicators of profitability (ROE, ROA, NMR) and independent variable QMS, with the combination of variables banking services in Kosovo (NB, NE, ATM, POS, E-Banking).

$$
\begin{aligned}
& \text { Performance } t=C+\beta_{1} T_{Q} M_{t}+\varepsilon \\
& C-\text { Constants for variables } \\
& E-\text { random error for period } t \\
& T-2000 \text { year to } 2015 \text { years. }
\end{aligned}
$$

Table 7. Results of simple linear regression

Coefficientsa

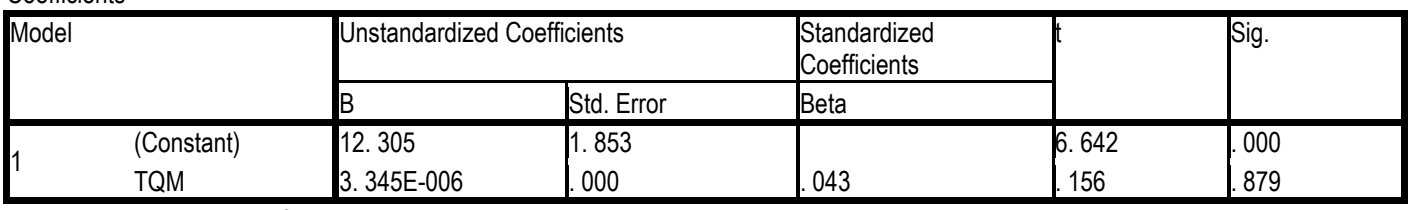

a. Dependent Variable: Performance

Source author / Calculation SPSS 3

The results of linear regression show that the level of significance is 0879 , which shows that QMS isn't an element that has had an impact on the quality of banking services and had no impact on the performance of the banking sector in Kosovo, a parameter indicating that banks in Kosovo are not oriented to offer quality services for the achievement of meeting the needs of customers, but they are more oriented to less quality services to achieve their financial goals. The The level of significance rejects the hypothesis $\mathrm{H}_{1}$ ad approves the hypothesis $\mathrm{H}_{0}$ that the application of the Quality Management System (QMS) and its requirements in the banking services sector has not affected the performance of the banking sector in Kosovo.

\section{Conclusions}

The paper empirically treated the problem of the impact of QMS in the performance of the financial sector in Kosovo, with particular emphasis on the banking sector in Kosovo, where the used empirical treatment in the paper is correlated with complete data available for this problem in Kosovo. The conclusion of the paper is that the application of the requirements of Quality Management System in the banking sector in Kosovo is still not at the right level, respectively nonsignificant between QMS and banking sector performance.

The current economic situation and the positions taken by banks present on the Kosovar market make the implementation of quality management within the banking system more important than ever. Thus, from these results we can say that the banking sector in Kosovo, still does not comply with quality services and does not take into account the "Voice of the Customer", which represents desires, thoughts, perceptions, expectations, demands and specifications of users and based on these financial institutions to produce services that meet the requirements of users and also to eliminate the possible failures that occur upon the offering of banking services. The banks that will be able to adequately combine its sales offer with the quality of service have real chances to increase their market share (what all banks are striving for) and, implicitly, their profit. 


\section{References}

[1] Nagaprasad, H. and Yogesha, B. (2009). Enrichment of customer satisfaction through total quality management techniques, retrieved on 4th December 2012

[2] Goodman, A. J., and A. Colin. 1992. Measuring customer service to enhance the bottom line. Marne-la-Vallee: Tarp Europe

[3] Ahonen Paula (1999). Customer's satisfaction, seminar on quality management - June 1999, Paris

[4] Islam. A. and Haque, A. F. M. (2012). Pillars of TQM implementation in manufacturing organization- an empirical study, Journal of Research in International Business and Management, Vol. 2(5) p. 128-141

[5] Cowling, A. \& Newman, K. (1995). Banking on people: TQM, service quality and human resources, Personal Review, 24(7), 25-40.

[6] Buttle, F. (2011): Customer Relationship Management, Concepts and Technologies. Francis Buttle first edition 2009, reprinted 2009, 2010, 2011.

[7] Sadeghi T., Bemani A., Assessing the Quality of Bank Services by Using the Gap Analysis Model, Asian Journal of Business Management Studies 2 (1), 2011., page. 14

[8] Tyler, K. and Stanley, E. (2001), "Corporate banking: the strategic impact of boundary spanner effectiveness", International Journal of Bank Marketing, Vol. 19,6, 246

[9] Berry, L. (1995) 'Relationship marketing of services - growing interest, emerging perspectives', Journal of the academy of marketing science, 23(4), p. $236-245$.

[10] Gronroos Christian, 2004, 'The relationship marketing process: communication, interaction, dialogue, value', Journal of Business \& Industrial Marketing, MCB University Press Hanken Swedish School of Economics, Helsinki, Finland, Volume 19, Number 2, p. 99, 104

[11] Harvey, T. The banking revolution: position your bank in the new financial services marketplace. Chicago, Irwin Professional Publishing, 1996.

[12] Appiah-Adu et al, 2001, 'Marketing effectiveness and business performance in the financial services industry', Journal of Services Marketing, MCB University Press, Volume 15, Number 1, p. 24

[13] ISO 9001:2015, Quality management systems — Fundamentals and vocabulary, International Organization for Standardization, Geneva,Switzerland

[14] Banking and Payments Authority of Kosovo, Annual Report (2000);

[15] Banking and Payments Authority of Kosovo, Annual Report (2001);

[16] Banking and Payments Authority of Kosovo, Annual Report (2002);

[17] Banking and Payments Authority of Kosovo, Annual Report (2003);

[18] Banking and Payments Authority of Kosovo, Annual Report (2004);

[19] Banking and Payments Authority of Kosovo, Annual Report (2005);

[20] Central Banking Authority of Kosovo, Annual Report (2006);

[21] Central Banking Authority of Kosovo, Annual Report (2007);

[22] Central Bank of the Republic of Kosovo, Annual Report (2008);

[23] Central Bank of the Republic of Kosovo, Annual Report (2009);

[24] Central Bank of the Republic of Kosovo, Annual Report (2010);

[25] Central Bank of the Republic of Kosovo, Annual Report (2011);

[26] Central Bank of the Republic of Kosovo, Annual Report (2012);

[27] Central Bank of the Republic of Kosovo, Annual Report (2013);

[28] Central Bank of the Republic of Kosovo, Annual Report (2014);

[29] Central Bank of the Republic of Kosovo, Annual Report (2015); 